and constructed has proved a useful asset in the prosecution of the Laboratory's researches, and has frequently been made use of by industrial firms and other organisations. Other subjects under investigation are the production of various useful chemicals by catalytic hydrogenation and amination. A study is elso being made of the preparation and polymerization of substances containing silicon. The Organic Intermediates Section also played a useful part in the development of the new synthetic fibre 'Terylene'.

Items of biological or agricultural interest which have been investigated in recent years or are still under investigation include the discovery of one drug of outstanding properties. This substance, 2 : 7-diamino-9-phenyl-10-methyl-phenanthridinium bromide, or C.R.L.1553, has been widely used against nagana, a trypanosome disease of cattle in Africa.

In order to make further use of Colonial products, research was carried out by the Microbiological Group of the Laboratory into the production of food yeast from molasses. Yeast production up to a pilot-plant stage was successfully achieved using a special strain of yeast, and the process is now in the course of fullscale production in Jamaica.

In collaboration with stations of the Agricultural Research Council, effective sheep dips and sprays containing D.D.T. have been formulated against blowflies and sheep ticks, and special tar-acid emulsions were developed as a substitute for sulphuric acid in the destruction of potato haulm. The future policy of the Laboratory will be to extend these fruitful fields of discovery, to broaden the range of techniques available and to make the work of the Laboratory of the maximum possible value to British industry and to the chemical community as a whole.

\section{NUTRITION IN NEWFOUNDLAND*}

\begin{abstract}
A STUDY of the history of Newfoundland should convince even the most hardened opponent of the need for Government planning. This island, a little larger than Ireland, a little smaller than England, has now some 320,000 inhabitants, mostly descendants of the original settlers who came from the British Isles. These settlers established themselves on the basis of one industry-cod-fishing-and sold their dry salt cod in many markets of the world. They bothered little about agriculture, and they soon depleted the stocks of game which once enriched the interior. This dependence on a single 'cash crop' meant that a bad year or a fall in the demand for their product not only spelt economic distress at the time but also resulted in a general downward trend from which the community was unable to extricate itself. In 1934 it was found necessary to suspend Dominion status.
\end{abstract}

As might be expected, this economic degradation showed in the health of the people : in a high infantile mortality-rate, in the number of still and premature births, in the incidence of tuberculosis, and in various clinical signs of malnutrition, including sporadic outbreaks of dry beriberi. In 1944 it was decided to copy the American plan of 'enriching' white flour with iron and some B-vitamins; but measures far more comprehensive than that are needed if Newfoundland's sickness is to be cured. Fortunately, there are now signs that this fact is recognized.

- Report on Nutrition in Newfoundland. By Dr. D. P. Cuthbertson. Pp. 87. (Dominions No. 4.) (London: H.M. Stationery Office, 1847.)
18. 6d. net.
The nutrition workers who carried out the "Medical Survey of Nutrition in Newfoundland" in August 1944 were not content merely to report their clinical findings, but also submitted to the Commissioner for Public Health and Welfare specific recommendations for dealing with the situation, and they advised the setting up of a Council of Nutrition, "to include senior members representative of all the Departments concerned in the promotion of better nutrition of the people of the country". These recommendations were accepted by the Department of Public Health and Welfare as being "sound and essentially capable of being implemented", and a year later Dr. D. P. Cuthbertson, of the Medical Research Council, visited the island to advise on "the ways and means of approaching the programme in the field".

His report reviews the evidence compiled by the various surveys that had been made and discusses in detail the pros and cons of different methods of implementing the recommendations. The arguments range over such problems' as 'enrichment' versus higher extraction rates for flour, 'uneconomic' local milk production versus imported processed milk, etc., and are therefore of interest to other territories besides Newfoundland.

From it all emerges, quite clearly, the fact that this programme for the attainment of good nutrition is going to make demands on agriculture, education, transport, industry and, not least, on the people themselves. Planning and direction are essential for, in Dr. Cuthbertson's own words, "Newfoundland -. cannot, as at present constituted, exist as a sound economic unit capable of improving its social services so that there is freedom from want and disease".

M. W. GranT

\title{
QUANTUM ELECTRODYNAMICS
}

THE subject of quantum electrodynamics is 1 extremely difficult, even for the case of a single electron. The usual method of solving the corre. sponding wave equation leads to divergent integrals. To avoid these, Prof. P. A. M. Dirac* uses the method of redundant variables. This does not abolish the difficulty, but presents it in a new form, which may be dealt with in two ways. The first of these needs only comparatively simple mathematics and is directly connected with an elegant general scheme, but unfortunately its wave functions apply only to a hypothetical world and so its physical interpretation is indirect. The second way has the advantage of a direct physical interpretation, but the mathematics is so complicated that it has not yet been solved even for what appears to be the simplest possible case. Both methods seem worth further study, failing the discovery of a third which would combine the advantages of both.

There is another fundamental problem in quantum electrodynamics. The classical theory disagrees with experiment, in that it allows a charged particle, in the absence of an ingoing field, to build up an acceleration and to radiate energy. This difficulty can be overcome in the classical theory by imposing the extra condition that the final acceleration must be zero. In quantum electrodynamies, the first of the new methods mentioned above does not seem to need any extra condition. On the other hand, the

" "Developments in Quantum Electrodynamics", Communications of the Dublin Institute for Advanced Studies A3, 1946. 
second method does need an extra condition, but it is not at all clear what form it should take.

Theoretical physics is much more complicated than it appeared earlier in this century. About thirty years ago it seemed that all physical quantities were expressible in terms of tensors. The discovery of the wave equation of the spinning electron showed that we needed also spinors. Now Prof. Dirac shows that for quantum electrodynamics we need a new kind of quantity with components which transform linearly under Lorentz transformations, which he calls an 'expansor'. It has an enumerably infinite number of components.

\section{FORTHCOMING EVENTS}

Monday, July 28-Saturday, August 2

Physical Society, Colodr Grodp (at Cambridge).-Conference on "Colour Vision".

\section{APPOINTMENTS VACANT}

APPLICATIONS are invited for the following appointments on or before the dates mentioned:

Assistant LECTURIR (temporary) IN PHILOSOPHY-The Secretary and Registrar, University College of North Wales, Bangor (August 1) LECTURER IN APPLIED MECHANICS at the Royal Naval College,
Greenwich-The Director, Education Department, Admiralty, London, W.1 (August 2)

SENIOR LECTURER IN ENGINEERING, and a LECTURER IN ENGINEERING OR ENGINEERING M.ATHEMATICS-The Principal, Royal Aircraft Establishment Technical College, Farnborough, Hants (August 2) LECTURER IN ENGINEERING PHYSIOS, to work in the Electrical Thineering Department of Queen Mary College and the ElectroThe Registrar, Queen Mary College, Mile End Road, London, E.1 (August 2)

LECTURER IN ELECTRICAL ENGINEERING, a LECTURER IN AUTOMOBLLE ENGINEERING, a LECTURER IN MECHANICAL ENGINEERING SUBJECTS, a WELDING AND SHEET METALWORK INSTRUCTOR, and LECTURER IN BIOLOGY, at the Blackpool Technical College and School of Art-The Chief Education Officer, Education Offices, 3 Caunce Street, Blackpool (August 2).

Assistant well qualified to teach MEchanical and Electricat ENGINEering SUbJECTS, at the Bolton Municipal Technical CollegeThe Chief Education Officer, Education Offices, Nelson Square, Bolton (August 2).

LECTURER IN MECHANICAL ENGINEERING-The Director of Education, The Polytechnic, 309 Regent Street, London, W.1 (August 2).

LECTURER IN ELEOTRICAL ENGINEERING, and a HECTURER IN Mechanical Enginenring-The Principal, Paisley Technical College, Paisley (August 2).

PRINCIPAL OF THE TRChNIOAL College shortly to be established in Salisbury-The Director of Education, County Hall, Trowbridge, Wilts, endorsed 'Salisbury Technical College' (August 6).

JUNIOR PHYSICIST for research in connexion with medical applications of artiflcial radio-elements- The Director. Research Unit, Hammersmith Hospital, Ducane Road, London, W.12 (August 7).

LiCTURER IN ELEOTRICAL ENGINEERING-The Secretary, The University, Edmund Street, Birmingham 3 (August 12)

RESEARCH CHEMIST at the National Gallery, London-The Ministry of Labour and National Service, Technical and Seientific Register, koom 171, York House, Kingsway, London, W.C.2, quoting F.512.47A (August 12).

SENIOR DIETITIANS and JUNIOR DIETITIANS to the Ministry of Food-'The Ministry of Labour and National Service, Technical and Scientifle Register, Room 171, York House, Kingsway, London, W.C.2, quoting G.248.47A (August 14)

JUNIOR PROFESSTONAL OFHICER (woman) IN THE BRANCH OF BOTANY AND PLANT PATHOLOGY, Department of Agriculture, Southern Rhodesia-The Official Secretary, Office of the High Commissioner for Southern Rhodesia, 429 Strand, London, W.C.2 (August 15).

REGISTRAR OF RHODES UNIVEusity CoLlegu, Grahamstown-The Secretary, Office of the High Commissioner for the Union of South Africa, South Africa House, Trafalgar Square, London, W.C.2 (August 15).

Assistant VeterinaRY INVESTIGATION OFFICER-The Secretary, West of Scotland Agricultural College, 6 Blythswood Square, Glasgow,

C.2 (August 15).
Assistant PHYsicisT-The Secretary, University College Hospita1, Gower Street, London, W.C.I (August 15).

LECTURER IN PHARMACOLOGY-The Dean, Guy's Hospital Medical School, London, S.E.1 (August 15).

ASSISTANT (able to undertake instruction in Mathematics) IN THE DEPARTMENT OF MECHANICAI ENGINEERING, and an ASSISTANT (able GROLOGY - The Secretary, School of Mines, Camborne (August 23).

GoLOGY - The Secretary, School of Mines, Camborne (August 23).

ASSISTANT 1,EOTURER or LECTURER IN THE DHPARTMENT OF PHYSICS LEC'URER (Grade IIc) IN THe, Cathays Park, Cardiff (August 23). Secretary, The University, Edmund Street, Birmingham 3 (August 25) Secretary, The University, Edmund Street, Birmingham 3 (August 25). LECTURER IN MEDICINE-The Sect
Street, Birmingham 3 (August 31).
SENIOR SCIENTIFIC OFFICER in the Food Investigation organisation of the Department of Seientific and Industrial Research for work in a small laboratory at Smithfleld, London, in association with the Low Temperature Research Station, Cambridge-The Secretary, Civi Service Commission, 6 Burlington Gardens, London, W.1, quoting No. 1943 (September 1)

SENIOR LECTURER IN GEOLOGY at the Canterbury University College, Christchurch, New Zealand-The Secretary, Universities Bureau of the British Empire, 8 Park Street, London, W.1 (September 1). LECTURER IN GROGRAPHY - The Secretary; Queen's University, Belfast (September 7)

CHAIR OF CIVIL ENGINEERING at the University of Cape Town-.
The Secretary, Universitics Bureau of the British Empire, 8 Park The Secretary, Universitics Bureau of the British Empire, 8 Park treet, London, W.1 (September 12)

PROFESSOR OF FINE ART (and Director of the Michaelis School of Fine Art); SENIOR LECTURERS IN (a) ZOOLOGY, (b) COMMERCE ; LECTURERS IN (a) GEOGRAPHY (2), (b) PHYSICS, (c) PURA MATHEMATICS $(2),(d)$ FRENCH ; SUPERVISOR OF FTELD WrRK (Social Science), in the University of Cape Town-The Secretary, Universities Bureau of the British Empire. 8 Park Street, London, W.1 (September 15). SENIOR RESEARCH FELLOW IN THE DEPARTMENT OF CHEMISTRY, University of Melbourne-The Secretary, Universities Bureau of the British Empire, 8 Park Street, London, W.1 (Melbourne, September 30) Faculties, University Registry, Oxford (October 1).

EXPERT iN TOBACCO GROWING (M.N.18166), AgrICUTJURAL INSTRUCTOR IN TOBACCO GROWING (M.N.18167), for the tobacco monopoly of the Government of Iraq; TOBACCO BREEDING SPECIALIST (M.N. 18181), for the Directorate General of Agriculture, Iraq-The Crown priate Ref. No.

MECHANIC for experimental laboratory workshop in DEPARTMENT OF BIOCHEMISTRY, a TECHNICIAN IN THE DFPARTMENT OF ZOOLOGY, and a TeChNICIAN IN THE DEPARTMENT OF PHARMACOLOGY-The Establishment Officer, University College London, Gower Street, London, W.C.1.

ASSISTANT LECTURER IN GEOGRAPHY-The Secretary, Queen's University, Belfast.

Head of the Physics Department-The Principal and Clerk to the Governing Body, Wigan and District Mining and Technical College, Wigan.

EXPkrts IN Agronomy (M.N.18175), Plant Pathology (M.N. 18176), PLANT NUTRITION AND FERTILIZERS (M.N.18182), COTTON BREEDING (M.N.18177), SHEEP BREEDINA (M.N.18178), FORAGE CROPS M.N.18185), BIOMETRY (M.N.18186), PLANT BREEDING (M.N.18187), AGRICULTURAL EXTENSION AND D DMONSTRATION WORK (M.N.18179), for the Colonies, 4 Millbank, London, S.W.1, quoting appropriate Ref. No.

Ref. No.
LECTURER IN CHEMTCAL ENGINEERING-The Head of the Department of Chemical Engineering and Applied Physical Chemistry, Imperial College of Science and Technology, South Kensington, London, S.W.7

UNIVERSITY ASSISTANTSHIP IN THE DEPARTMENT OF BIOCHEMISTRY -The Secretary, The University, Edinburgh.

LECTURER IN BroLogY-The Registrar, Municipal College, Portsmouth.

Assistant ENGINEeR or TEChNiclan FOR X-RAY DEPARTMENT, and a Sanion Assistant Pfrsicist-The Secretary, Mount Vernon Hospital and the Radium Institute, Northwood, Middx.

RESEARCH STATISTICIAN, an ASSISTANT STATISTICIAN, and a MATHEMATICAL COMPUTER-The Secretary, Rothamsted Experimental Station, Harpenden, Herts.

Department of Chemistry, Malayan Union and Singapore-The Director of Recruitment, Colonial Service, 5 Victoria Street, London, S.W.1.

LECTURER IN ELEOTRICAL ENGINEERING--The Clerk to the Governors, Heaton Technical Institute, 12 Chapel Street, Marlpool, Heanor, Nottingham.

LECTURER IN MINING at the Cannock Chase Mining College-The Director of Education (Dept. F.E.), County Education Offices, Stafford.

\section{REPORTS and other PUBLICATIONS (not included in the monthly Books Supplement)}

Great Britain and Ireland

British Rubber Producers' Research Association. Publication No. 72: Modern Views on the Chemistry of Vulcanization Changes, Part 1, Nature of the Reaction between Sulfur and Olefins, by $\mathrm{F}$. by Ralph F. Naylor; Part 3, Reaction of Sulfur with Squalene and by Raiph F. Naylor; Part 3, Reaction of Sulfur with Squalene and with Rubber, by George F. Bloomfleld. Pp. 26. Publication No. 73 A Simple Laboratory Falling-Film Molecular Still. By E. Harold Farmer and D. A. Sutton. Pp. 4. Publication No. 74: Kinetic Studies in the Chemistry of Rubber and Related Materials, 2, The Kinetic of Oxidation of Unconjugated Olefing; 3, Thermochemistry and Pp. 18. (London: British Rubber Producers' Research Association, 1946.) (301] British Electrical and Allied Industries Research Association. Twenty-sixth Annual Report, October 1, 1945, to September 30,
1946. Pp. 148. (London: British Electrical and Allied Industries 1946. Pp. 148. (London: British Electrical and Allied Industries
Research Association, 1947.)

\section{Other Countries}

Smithsonian Miscellaneous Collections. Vol. 106, No. 16: New Birds from Colornbia. By Alexander Wetmore. (Publication 3862 . Pp. if +14 . Vol. 106, No. 17: Some New Cambrian Bellerophont Gastropods. By J. Brookes Knight. (Publication 3865.) Pp. ii + $11+2$ plates. (Washington, D.C.: Smithsonian Institution, 1946Classit)

Classifled List of Smithsonian Publications available for Distribution December 1, 1946. Compiled by Helen M.onroe. (Publication 3858.)
Pp. iv + 53. (Washington, D.C.: Smithsonian Institution, 1946.) [291 